\title{
The Supervisor's Support For Silence And The Organizational Commitment: The Mediating Role Of Organizational Silence Behavior
}

\author{
Adel R. M. Rayan, Nadia A. M. Ali, and Mostafa S. K. Abdel Moneim
}

\begin{abstract}
The aim of this study was to test the relationship between supervisor support for silence and organizational commitment, as well as testing the relationship between supervisor support for silence and organizational silence behavior. The study also aimed to identify the relationship between organizational silence behavior and organizational commitment, as well as the test of the mediation role of silence behavior in the relationship between supervisor support for silence and organizational commitment.

The study was applied to a sample of (365) employees from Assiut university in Egypt. The current study used Brinsfield (2009) scale to measure the supervisor support for silence, and organizational silence behavior which was prepared based on several studies (Morrison \& Obligation either, Melliken; 2000; Pinder \& Harlos, 2001; Vakola \& Buradas, 2005) where the organizational commitment was measured by Morrow (1983).

Data analyzed using the SPSS program Data, as well as the AMOS program to test the quality of compatibility between data collected and theoretical data, and the structural model to test the hypotheses of the study.

The study found that there is a negative relationship between the supervisor's support for silence and the organizational commitment. There is a positive correlation between supervisor support for silence and organizational silence behavior and a negative relationship between the behavior of organizational silence and organizational commitment. The study also found that the Organizational Silence behavior mediated the relationship between Supervisor's support for silence and the Organizational Commitment. Directions for managerial implications are recommended to Assiut University. The study ended with the limitations and avenues for future research.
\end{abstract}

Index Terms - organizational silence, Supervisor support for silence, organizational commitment

\section{INTRODUCTION}

Supervisors play an important role in managing the work and achieving the organization's objectives. They work closely with the subordinates and employees. They represent a role model for their subordinates. The relationship with the supervisor is one of the most important factors influencing the behavior and attitudes of the employees in organizations, including the silence behavior, and that the supervisor may be more important than the organization (as a system) in influencing the behavior of silence.. To react closely with subordinates, the supervisor is usually aware of their behavior over time, and aware of this behavior according to

Published on March 14, 2020.

Adel R. M. Rayan, Egypt- Japan University of Science and Technology,

Egypt. (email: rayan@aun.edu.eg)

Nadia A. M. Ali, Assiut University’ Egypt.

(email: nadia@aun.edu.eg)

Mostafa S. K. Abdel Moneim, Assiut University' Egypt.

(email: mostafakh2084@gmail.com) his/her interpretation and evaluation of this behavior.

In contrast to top and middle managers, first-line managers (supervisors) typically spend a large proportion of their time supervising the work of subordinates [11]. At the same time, supervisors sometimes have a double-edge sward effect in organizations. That is to say that negative and abusive suppression may lead to negative employee outcomes and reactions. Managers who believe that their subordinates are not trustworthy or unreliable, they prevent their relationships, explicitly. [24].

Negative attitudes that supervisor holds about subordinates may lead to organizational silence behavior. This type of behavior (organizational silence) is made when employees haven't the opportunity to speak up and discuss the decisions made by their supervisors.

Organizational silence by itself may lead to negative attitudes and behaviors among employees. It contributes to employees' burnout [2], organizational commitment, and organizational citizenship behavior [19].

On the other hand, many employees in different organizations have recognized that the organizations they work for do not support communication, information sharing and knowledge, which is a major problem for organizations. [37]- [21]. So it can be said that the prevalence of organizational silence can be of a major threat to the organization. Morrison noted that many institutional disasters - such as the "Colombia" Flight No. 173 of the United Airlines aircraft, the collapse of Enron Energy and the explosion of Petroleum's oil platform has been exacerbated by staff failure to communicate information about irregularities, and the prevailing mistakes to officials in positions of authority [17].

It is considered that for all organizations in general, and educational institutions (e.g. universities) in particular that organizational silence behavior is an important area of study, and in recent years many studies have been conducted in organizational silence in educational institutions [1].

If the employees are practicing the organizational silence behavior and their supervisors are supporting silence, this may lead to many consequences including resisting change [19], and may be lower employee organizational commitment. Based on that, this paper is attempting to pursue research efforts in this area. The current study will focus on examining the mediating role of organizational silence behavior in the relationship between supervisor support for silence and organizational commitment of employees at Assiut University. 


\section{PRIOR Literature AND HYPOTHESES}

\section{A. The supervisor's support for silence and organizational commitment:}

Employee with high degree of loyalty to the supervisor is more conducive to conduct what is consistent with the supervisor's desire. Employees believe that the supervisor will observe, and reward the behavior that corresponds to his/her orientation. This because the supervisor is one of the most important parties in the organization, acts as its representative, and often interacts with staff on a daily basis, and performs the formal and sometimes informal functions of subordinates, as defined and there is a relationship between supervisor support for silence and organizational commitment [9].

Despite the clarity of the phenomenon of organizational silence in business organizations where there is no spirit of harmony, cooperation, and trust among staff, and in which the supervisor is increasingly supportive of silence, the effects of silence behavior are evident in employees suffering from negative consequences and effects that appear in reducing organizational commitment [15] -[4][13]- [22]- [27]. A study applied on a sample of (280) employees in (15) governmental institutions (electricity, gas, agriculture, social security, etc.) in Iran, found a negative relationship between supervisor attitudes to silence and organizational commitment [23].

In the same context, Panahi, et al (2012) using a sample of (260) of administrative staff in an Iranian University, identified the nature of the relationship between supervisors' attitudes towards silence and the organizational commitment of employees. Their study indicated that there is a negative relationship between the supervisor's attitudes towards silence and the organizational commitment [24] .

Fard \& Karimi (2015) study applied to a sample of (180) administrative personnel at the University of Azad (Islamic city) in Esfahan, reached a negative relationship of statistical significance between the supervisor's attitudes to silence and organizational commitment [8].

Based on the above literature, the first hypothesis of this study could be formulated as follows:

$\mathrm{H}_{1}$ : "There is a negative relationship between the supervisor support for salience and organizational commitment"

\section{B. Supervisor Support to salience behavior and organizational salience}

Some supervisors feel intimidated by their unsatisfactory performance and blame their subordinates. Employees that supervisors will directly or indirectly penalize them for the discovery of error(s), will resort to the behavior of silence. [33] - [34].

The power and status of the supervisor may increase or decrease employee silence. However, many researchers emphasize that there is an evidence that subordinates are more sensitive to the risk of the voice than its benefits, especially if the supervisor is powerful [7] - [16] - [26] . So, the silence behavior may increase with powerful supervisors who support silence [35].

Silence of the subordinates is influenced by the attitudes and tendencies of the supervisors towards silence more than by that of top management tendencies and attitudes. So, when employees listen to their supervisor, they consider $\mathrm{him} / \mathrm{her}$ as a role model and tend to involve themselves in work issues, and talk about them. The supervisory relationships according to Sparrowe \& Liden (2005) has a significant impact on the performance of subordinates, career paths, as well as on the rewards they receive [31].

Although the power and prestige of the supervisor can increase or decrease the silence of the subordinates, many of researchers believe that there is an evidence that subordinates are more sensitive to the risk of speech than its benefits. This may happen in the presence of a strong and influential supervisor [7] - [16]-[26]. So, it can be said that salience behavior can be increased with the presence of a supervisor who has a strong standing or influence in support of silence [35].

Morrison \& Milliken (2000) demonstrated that organizational silence is shaped by several factors, including: lack of mechanisms or opportunities for communication, and fear of counter-feeding of information received from subordinates [16]. So, supervisors do not tend to encourage their subordinates to talk because the information received from subordinates may include criticism of them. The lack of confidence in the supervisor helps to silence of the employee, and that the agreement is evidence of organizational health contrary to differences of views, and all these factors help the emergence of salience behavior, and its prevalence in organizations [16].

In the same context, Nikmaram, Yamchi, Shojaii \& Alvani (2012) in their study applied on a sample of faculty members and administrative staff in the Humanities and Management Departments in Tehran University, Iran, found several results, including a significant positive correlation between the supervisor support of silence and the organizational silence behavior [20].

A study applied on a sample of faculty members in Namek Kemal and Kocaeli universities in Turkey. The authors are partially studied the impact of trust in the supervisor on organizational silence, and reached that there a statistically significant positive effect of trust in supervisor on organizational silence behavior of faculty members at both universities [36].

Brinsfield (2013) study applied on a sample of MBA students and employees in some industrial companies in Minnesota (USA) to identify the causes of silence. The results showed that one of the main reasons for the silence is the support of senior management $(6.40 \%)$, followed by supervisor direct support to salience behavior (27.9\%). [3]. Based on the above noted results of prior studies, the second hypothesis can be formulated as follows:

\section{$\mathrm{H}_{2}$ : "There is a significant positive relationship between the supervisor support to salience and organizational salience behavior".}

\section{The organizational salience behavior and organizational commitment}

In recent years organizational commitment has become a significant concept in organizational behavior research. It aims to understand the behavior of workers in the work environment, reflecting their acceptance of the organization's goals and values. The previous studies revealed that there are many benefits to the organization of a 
high degree of organizational commitment to its employees [5] - [6] - [10] - [12] - [39].

The organizational silence behavior has many negative effects on organizations success and growth. Therefore, efforts should be made to eliminate or reduce these destructive effects.

Previous literature showed that the organizational silence behavior has serious implications for the future of organizations [13] - [22] - [25] - [27] - [30].

At the same time, the relationship between the organizational silence behavior and organizational commitment has a remarkable emphases in previous studies [5], [13], [22] and [27]. Nevertheless, it is an area that is still under discussion. Studies have examined the nature of the relationship between these two variables, and found a negative relationship between the organizational silence behavior and organizational commitment. It was found that, the more silence and the non-disclosure of opinions and ideas whenever it does, the lower the level of organizational commitment and reluctance to work. Another study in Egypt) applied on a public university found that organizational silence affects the organizational commitment and organizational citizenship behaviors [19].

Except Nafie (2016) study, all of these findings are reached in foreign countries but not in Egypt. So, this relationship between organizational silence behavior and organizational commitment needs to be examined in the Egyptian context. Based on the above noted discussion, the third hypothesis will be formulated as follows:

$\mathrm{H}_{3}$ : "There is a negative relationship between organizational silence behavior and organizational commitment".

\section{The mediation role of organizational commitment}

A study applied on a sample of (677) employees of a technology company in the United States of America, noted that the organizational silence behavior is considered to mediate the relationship between the antecedents of organizational silence behavior (top management attitudes and supervisors attitudes towards silence) and the professional commitment [37] .

Tangirala \& Ramanujam (2008) conducted a study of a sample of 606 nursing staff members within 30 working groups in American hospitals. In part, this study found that the behavior of organizational silence behavior is mediating the relationship between the power and status of the supervisor, and professional commitment [35].

The study of Panahi et al. (2012), which was applied on a sample of 260 administrative staff at Payame Noor University in Tabriz, Iran, showed that the organizational silence behavior is a mediating variable in the relationship between determinants of organizational silence behavior (Top management support to silence, supervisors attitudes towards silence and communication opportunities) and organizational commitment [24].

In the same context, another study applied on a sample of (121) employees ( 62 members of the teaching staff and 59 administrative staff) in the faculties of humanities and the administration in Tehran, Iran, and found that the organizational silence behavior is considered as a mediating variable in the relationship between determinants of organizational silence (support of senior management of silence, supervisor support for silence, communication opportunities) and organizational commitment [20] .

Based on the above noted studies, the fourth hypothesis of the study can be formulated as follows:

$\mathrm{H}_{4}$ : "The organizational silence behavior will mediate the relationship between supervisor's support for silence and organizational commitment".

\section{STUDY METHODS}

\section{A. Study Model}

Based on the prior literature, the study model could be formulated as follows:

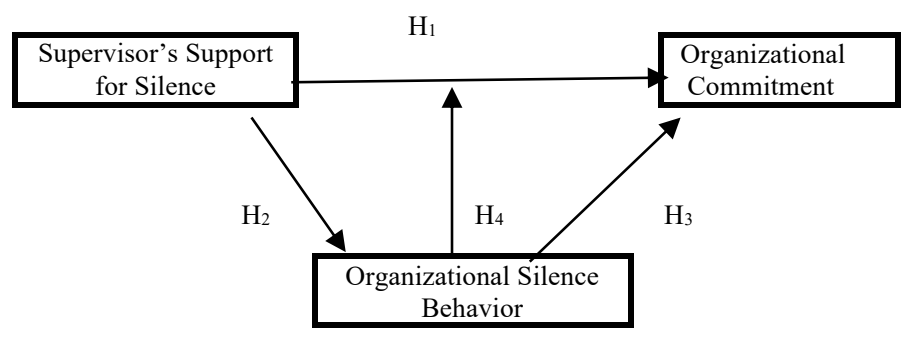

Fig.1. the hypothecate model of the study

\section{B. Population and Sample}

The population of the study consists of the administrative employees at the university central administration and their counterparts in the faculties (12 faculty) at Assiut University. The total number of employees in Assiut University is (10198). A sample of 370 employees has been selected with $98 \%$ of responses (365).

The staff completed the questionnaire, which includes the extent of the supervisor's support for silence and therefore the existence and spread of organizational silence behavior and their relation to organizational commitment. The questionnaire was translated into Arabic by the first author and completed by the employees in the central administration and the faculties.

\section{Measurement}

For purposes of data collection and testing of study hypotheses, the questionnaire was prepared using the Likert scale, which ranges from 1-5 (fully agreeable 5 and totally disagreeable 1).

The supervisor's support for silence (SSS) is measured by Nafei [19] scale derived from the original scale of Brinsfield [3], which consists of (5) statements (examples include: my direct supervisor doesn't care about negative information about my performance).

The second-order positive mass analysis of the scale was performed and results were acceptable $(\mathrm{X} 2 / \mathrm{df}=2.151$, CFI $=.936, \mathrm{RMSEA}=.056)$ after deleting one statement (SSS2). The $\alpha$-Cronbach coefficient of the scale is 0.82 ).

Organizational Silence Behavior (OSB) was measured based on the original scale used by several studies (Morrison \& Melliken, [16]; Pinder \& Harlos, [26]; Vakola \& Buradas, [37]). Examples of the scale include: (I keep 
silent during meetings when talking about sensitive work issues). The second-order positive mass analysis of the scale was performed and results were acceptable $(\mathrm{X} 2 / \mathrm{df}=$ 1.177 , CFI $=.999$, RMSEA $=.022)$ after deleting $(5$ elements) the OSB1, OSB6, OSB7, OSB8, OSB9, The Alpha Cronbach coefficient of the scale is 90.0.

Morrow scale [8] was used to measure the organizational commitment (OC). Examples of the scale statements include :( this university does not encourage me to make the maximum effort to achieve outstanding performance). The second order confirmatory analysis was run and the results were found to be acceptable (X2 /df $=2.718, \mathrm{CFI}=.996$, RMSEA = .069). After the deletion of one expression (OC1), the Alpha Cronbach coefficient (0.76).

\section{Statistical methods}

The study used the SPSS, method of confirmatory analysis and the method of path analysis available in the AMOS program to test the quality of compatibility between data collected and theoretical data, and the structural model to test the hypotheses of the study. Sobel test was used to test the mediation impact of organizational silence behavior [29].

\section{RESULTS}

\section{A. Descriptive Statistics}

Table (1) shows the means, standard deviation and the linear correlation coefficients between the study variables as follows:

TABle (1): MEAns, Standard DEVIATIONS AND CORRELATION

\begin{tabular}{lcccc}
\multicolumn{1}{c}{ Variables } & Mean & $\begin{array}{c}\text { Standard } \\
\text { Deviation }\end{array}$ & SSS & OSB \\
\hline \hline $\begin{array}{l}\text { Supervisor's Support for } \\
\text { Silence (SSS) }\end{array}$ & 3.52 & 0.99 & $(0.82)$ & \\
$\begin{array}{l}\text { Organizational Silence } \\
\text { Behavior (OSB) }\end{array}$ & 3.79 & 0.80 & ${ }^{* *} 126,0$ & $(0.90)$ \\
$\begin{array}{l}\text { Organizational } \\
\text { Commitment (OC) }\end{array}$ & 2.09 & 0.89 & ${ }^{* *} 154,0-$ & ${ }^{* *} 025,0-$ \\
\hline
\end{tabular}

*Correlation is significant at 0.05 . ${ }^{* *}$ correlation is significant at .01

Cronbach's Alpha is shown between brackets

As shown in the table (1), supervisor's support for silence (SSS) is positively correlated with organizational silence behavior (OSB) and negatively correlated with organizational commitment (OC). The organizational silence behavior (OSB) is negatively correlated with organizational commitment (OC).

\section{B. Hypotheses testing}

Figure (2) shows the structural model of the study:

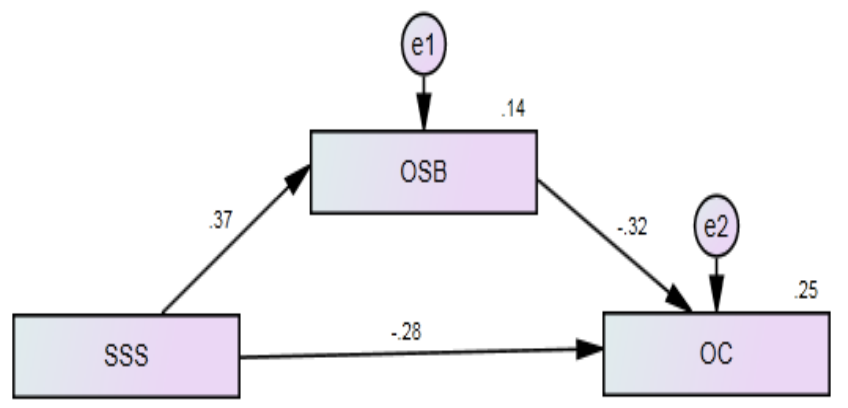

Fig. 2. The structural model of the study
The first hypothesis of the study indicates that there is a negative relationship between the supervisor support for silence and organizational commitment. The results support this hypothesis with a correlation of -0.28 and a value of SE $=0.047$ and $\mathrm{P}=0.000$ which means that the higher the supervisor's support for silence, the lower the organizational commitment of the employees.

The second hypothesis states that there is a positive relationship between the supervisor support for silence and the organizational silence behavior. The results support this hypothesis where the correlation coefficient is 0.37 and SE $=0.044$ and $\mathrm{P}=0.000$. This means that the higher the level of supervisor support for silence, the higher the organizational silence behavior of employees.

The third hypothesis states that there is a negative relationship between the oorganizational silence behavior and organizational commitment". The results of the study support this hypothesis with correlation of $-0.32, \mathrm{SE}=0.044$ and $\mathrm{P}=0.000$. This means that when the organizational silence behavior increases the organizational commitment decreases.

The fourth hypothesis indicates that the organizational silence behavior mediates the relationship between the supervisor support for silence and organizational commitment. Table (2) shows both direct and indirect effect between the study variables.

TABLE (2: RESULTS OF DIRECT AND INDIRECT EFFECTS BETWEEN STUDY VARIABLES

\begin{tabular}{|c|c|c|c|c|c|}
\hline \multicolumn{2}{|c|}{ Paths } & Total effects & $\begin{array}{l}\text { Direct } \\
\text { effect }\end{array}$ & $\begin{array}{c}\text { Indirect } \\
\text { effect }\end{array}$ & \\
\hline SSS & $\mathrm{OC}$ & -0.379 & -0.265 & -0.114 & \\
\hline \multicolumn{2}{|c|}{ Value of paths } & $\begin{array}{c}\text { Standard } \\
\text { Coefficient } \\
(\beta)\end{array}$ & $\begin{array}{l}\text { Standard } \\
\text { Error }\end{array}$ & $\begin{array}{c}\text { C.R value } \\
(\mathrm{T})\end{array}$ & $\mathbf{P}$ \\
\hline SSS & $\longrightarrow \mathrm{OC}$ & -0.265 & .047 & -5.643 & 0.000 \\
\hline OSB & $\longrightarrow \mathrm{OC}$ & -0.344 & .052 & -6.607 & 0.000 \\
\hline SSS & $\longrightarrow$ OSB & 0.332 & .044 & 7.574 & 0.000 \\
\hline
\end{tabular}

Results in table (2) indicate the effects of the supervisor support for silence, and the organizational silence behavior on organizational commitment. We note that there is a direct, negative, and significant effect of the supervisor's support for silence on organizational commitment $(\beta=$ 0.265 and $\mathrm{p}=0,000)$. Also, there is a direct, negative and significant effect of the organizational silence behavior on the organizational commitment $(\beta=-0.344$ and $p=0.000)$. We also note a positive direct effect of the supervisor's support for the silence on organizational silence behavior $(\beta$ $=0.332$ and $\mathrm{p}=0.000$ ).

For the indirect effects, it is noticed that organizational silence behavior is mediating the relationship between the supervisor's support for silence and the organizational commitment $(-0.114)$ as it increases the overall negative effect of the supervisor's support for silence on organizational commitment (-0.379).

To verify the above noted results, Sobel test was used. The mediation role of the organizational silence behavior is achieved when the estimated estimates are not less than 0.08 and the value $P$ is significant, and the standardized estimates can be obtained by multiplying the value of the first path 
(independent variable and mediator variable) by the second path (mediator variable and dependent variable).

This result is shown in the following table (3) obtained from the Sobel test as a result of the estimates $(0.344 \times 0.332)=$ 0.114 , the value of $\mathrm{T}=4.99$, and $\mathrm{P}=0.000$ ) which confirms that the variable behavior of organizational silence is a variable interstitial intermediary, and thus proves the validity of the fourth hypothesis.

TABLE (3): SOBEL TEST RESULTS FOR THE INDIRECT EFFECTS OF ORGANIZATIONAL SILENCE BEHAVIOR AS A MEDIATING VARIABLE

\begin{tabular}{ccccccc}
\hline \hline Exogenous & Endogenous & Mediation & Estimate & S.E & C.R & P \\
\hline SSS & OC & OSB & 0.114 & 0.024 & 4.99 & 0.000 \\
\hline \hline
\end{tabular}

\section{DISCUSSION}

The aim of the study was to investigate the relationship between the supervisor's support for silence and the organizational commitment, and also to test the relationship between the supervisor's support for silence and the behavior of organizational silence. The study also aimed to identify the nature of the relationship between organizational silence behavior and organizational commitment of the employees at Assiut University in Egypt.

The results supported the first hypothesis, which proved a negative relationship between the supervisor's support for silence and the organizational commitment, and this result is consistent with the results of previous studies [8]- [23]- [24]. This result can be interpreted in terms of the human nature and personality characteristics of the supervisor and his implicit beliefs. That is to say, some of the supervisors believe that if they are supportive of the behavior of silence in organizations, the individual can remain silent for fear of the supervisor. Employees who seek positions and gains usually try to satisfy their supervisors through the negativity and silence towards what is happening in the organization. Those employees see that the talk will not change anything and, laziness and silence are the best ways to please supervisors. This may be different from one culture to another.

The results of the study also support the second hypothesis, which showed a positive relationship between the supervisor's support for silence and the organizational silence behavior, which is consistent with the results of the previous studies. [16] - [20] - [36].

It can be said that: if the behavior of supervisors is supportive of silence, it will affect many aspects of the employees' behaviors in the organization. This is because of the influence of power of the supervisor on subordinates and the nature of the relationship between them, where the supervisor is one of the most important parties to the employees in organizations. The supervisor is the representative of the organization, and he/she is interacting with the employees in a daily basis. Also, he/she is controlling the rewards of the employees.

The employees do not dare to say what they think is the best, or that they are the best for the department or the university - concerning work-related issues - and may even disclose what they think leads to the satisfaction of their supervisors. A motive to act in accordance with the desire of the supervisor or the boss because of the belief that the supervisor will observe and reward the behavior that corresponds to his directions, and the more the supervisor supports the behavior of silence whenever engaged in the practice of organizational silence behavior to satisfy him/her.

The results also supported the third hypothesis, where the study proved a negative relationship between the organizational silence behavior and the organizational commitment. These results are on the line of the previous studies (e.g. [13] - [22] - [27]).

This result can be explained by the fact that administrative work at Assiut University was dominated by and spread of the organizational silence behavior, which may result in less creativity and innovation. Also, this result can be interpreted from another point of view, that innovation, constructive ideas and proposals are infanticide at work because of fear of talking on or discussing work-related issues. The personal interest may prevail over the public interest. This, in turn, will result in a lower organizational commitment of the employees.

The results also supported the fourth hypothesis, where the study showed a role of silence behavior on the relationship between the supervisor's support for silence and the organizational commitment. This result is consistent with the previous studies [24] - [37] - [35].

Based on the above noted result, it can be said that as the organizational silence behavior, the mediating variable, increases, the negative impact of supervisor support for silence increases. In other words, if the employees in the university feel that their supervisors are supporting silence behavior, they will be less committed to their organizations.

\section{MANAGERIAL IMPLICATIONS:}

The above noted results imply that administration at Assiut University should work with the silence behavior in two directions: The first direction is to deal with employees silence through openness, encouraging them to speak, and providing an anti-retaliation policy. This policy of protection against retaliation that may be practiced by the supervisor and should include clear, fair and transparent procedures by top management for self-reporting about supervisor's relation.

The protection policy could be carried out through the following:

- $\quad$ Activating the employee self-reporting about managers and direct supervisors reactions and retaliation.

- Reconsidering managers and supervisors selection techniques in a way that grantees selecting those who maintain transparency and fairness. This may lead to reduce the supervisors support for silence.

- Maintain employee support and encouraging them to suggest and provide new ideas related to their work

- Reinforcing the role of decision support departments in collecting and analyzing data provided by employees to overcome the managers fear from the direct feedback provided by employees

- Deepening the team spirit and positive participation of employees in decision making process.

- Encouraging and supporting social activities to bring employees closer and increase their morale.

The second direction is to work with supervisors because they play an important role in in supporting the silence behaviors at work. This implies that some interventions are needed by the university and faculties administrations to 
create a climate of openness and transparency among their employees. This could be done through the following:

Training of supervisors on team work and team spirit is needed.

Also it is important to increase their awareness of the value and benefits of employees' voice.

Open door policy may help in keeping top management informed about any supervisors; abusive actions. This may lead to decrease the supervisors support for silence.

Maintaining a fair procedures as part of the university governance to create a healthy climate at work.

\section{LIMITATIONS AND FUTURE RESEARCH}

The supervisor's support for silence has been examined in general without considering the supervisor's style of management. That is to say that the supervisor's support for silence might be different from one style of management to another [28]. On the other hand, organizational commitment has been measured as one construct using Morrow scale (1983). Other scholars studied the relationship between organizational commitment and organizational silence using Alan -Mayer model with the three dimensions [14].

This study dealt with the organizational silence behavior as one construct (totally). However, organizational silence behavior has different types such as defensive silence, prosocial silence and acquiescent silence [32]. That is to say that employees reactions will be different according to the different types of silence they tend to adapt. So, the mediation effect of organizational silence behavior on the relationship between the supervisor's support for silence and organizational commitment may be different from one type of organizational silence behavior to another.

The study examined both direct and indirect effects of the supervisor's support for silence on the organizational commitment. Both direct and indirect relationships between the two variables are found to be negative. However, the organizational commitment is usually affected by a group of variables such as organizational justice and organizational ethical climate [38]. So there is a need to study other variables and determinants that may affect directly or indirectly the relationship between the supervisor's support for silence and organizational commitment of employees' such as the employees' perception of procedural justice and other variables related to the organizational commitment of the employees.

Future research may approach the relationships investigated in the current study considering the above noted dimensions of all variables (Organizational silence, supervisor's support for silence and organizational commitment).

\section{CONCLUSION}

The results showed that there was a statistically significant negative correlation between the perceptions of employees of the supervisor support of silence -at Assiut University and their organizational commitment. Thus we may conclude that : The higher the level of awareness of employees of the supervisor's support of organizational silence the negative the impact on the level of organizational commitment of employees at the university, and vice versa.
Also, findings of the study proved the significant and positive correlation between the employees' perception at Assiut University to the supervisor's support of silence, and the organizational silence.

There was a support from the supervisors for organizational silence in units and administrative contexts at the university. So, the greater the supervisors' support for silence, the more frequent organizational silence behavior among employees.

The study revealed that there is a statistically significant negative correlation between the employees' perception of organizational silence behavior, and organizational commitment at Assiut University. It could be concluded that the more the organizational silence perceived and practiced the less the organizational commitment exposed by the employees. This negative relationship may result in lower performance, lower job satisfaction and lower citizenship behaviors at work [8].

Also, the study found that there is an indirect effect of organizational silence behavior as a mediating variable on the path of the relationship between the supervisor's support for silence, and the organizational commitment. It is obvious that the organizational silence behavior as mediating variable plays an important role in reinforcing the negative impact of the supervisor's support for silence on organizational commitment.

\section{REFERENCES}

[1] Akar, H. "Organizational Silence in Educational Organizations: A meta-analysis Study", International Journal of Eurasia Social Sciences", Vol. (9). NO. (32), PP: 1077-1098, 2018.

[2] Akin, U. \& T. Uluosy, T. , The Relationship between Organizational Silence and Burnout among Academicians: A Research on Universities in Turkey, International Journal of Higher Education, Vol. 5, No. 2, pp:46-58, 2016.

[3] Brinsfield. C. "Employee Silence Motives: Investigation of Dimensionality and Development of Measures", Journal of Organizational Behavior, Vol. (34), No. (5), PP: 671- 697, 2013. http://onlinelibrary.wiley.com/doi/10.1002/job.1829/epdf.

[4] Dedahanov. A. T. \& Rhee, J. "Examining the Relationships among Trust, Silence and Organizational Commitment", Management Decision, Vol. (53) Iss. (8), PP: 1843 - 1857, 2015 available: http://www.emeraldinsight.com/doi/pdfplus/10.1108/MD-02-2015$\underline{0041}$

[5] Deniz,N. Noyan, A. \& Ertosun, O. G. . "The Relationship between Employee Silence and Organizational Commitment in a Private Healthcare Company". Social and Behavioral Sciences, Vol. (99), PP: $691 \quad$ - 700, $2013 \quad$ available: http://www.sciencedirect.com/science/article/pii/S187704281303985 $\underline{2}$

[6] Doigham.S. R.. "Relationship between Organization Work Climate \& Staff Nurses Organizational Commitment", Nature and Science, Vol. (10), No. (5), PP: 80-91, 2012 available: http://www.sciencepub.net/nature/ns1005/009 9000ns1005 80 91.pd

[7] Edmondson, A. "Learning from Mistakes is Easier Said than Done: Group and Organizational Influence on the Detection and Correction of Human Error", Journal of APP: Lied Behavioral Sciences, Vol. (32), no. (1), PP: 5- 28, 1996.

[8] Fard, P. G. \& Karimi.F. "The Relationship between Organizational Trust and Organizational Silence with Job Satisfaction and Organizational Commitment of the Employees of University" International Education Studies, Vol. (8), No. (11), PP: 219-227, 2015. available: http://files.eric.ed.gov/fulltext/EJ1082147.pdf

[9] Farh,,J .L. Podsakoff,P. M. \& Organ,D. W. "Accounting for organizational citizenship behavior: Leader fairness and task scope versus satisfaction", Journal of Management, Vol. (16), No. (4), PP: 705-721, 1990, available: http://journals.sagepub.com/doi/abs/10.1177/014920639001600404

[10] Gary, J. "Organizational Behavior: Understanding and Managing Life at Work", New York: Harper Collins College Publishers, 2002.

[11] Griffin, R. W. Management, New Delhi: Biztantra, Indian Edition 2005. 
[12] Harrison. G. "Culture and Management", Australian Accountant Journal, Vol. (64), No. (10), PP: 14-22, 2006.

[13] Hussain, W. H. Ali, A. Khalid,M. \& Shafique. M. N "Organizational Silence: A Predictor of Organizational Commitment in Higher Education Institution ", Developing Country Studies, Vol. (6), No. (2), PP: 123-128, 2016, available: http://www.iiste.org/Journals/index.php/DCS/article/view/28628/2939 0

[14] Korkmaz, E. The Relationship Between Organizational Silence and Allen-Meyer Organizational Commitment Model: A Research In The Health Sector In Turkey, Bilecik Şeyh Edebali University Journal of Social Sciences Institute, vol. (3), No. 1, pp:200-213, June,2018.

[15] Laeeque,S. H. \& Bakhtawari,, N. Z. "Employee Silence as A Determinant of Organizational Commitment: Evidence from the Higher Education Sector of Pakistan", European Journal of Business and Management, Vol. (6), No. (2), 46-51, 2014, available: http://citeseerx.ist.psu.edu/viewdoc/download?doi=10.1.1.687.5091\& rep=rep1\&type $=$ pdf

[16] Morrison,E. W. \& Milliken, F. J. . "Organizational Silence: A Barrier to Change and Development in a Pluralistic World", Academy of Management Review, 25(4), 706-725, 2000, available: http://amr.aom.org/content/25/4/706.short

[17] Morrison. E. W. "Employee Voice Behavior: Integration and Directions for Future Research", Academy of Management Annals, Vol. (5), no. (1), 373-412, 2011, available: http://annals.aom.org/content/5/1/373

[18] Morrow, P. C.,. "Concept Redundancy in Organizational Research: The Case of work Commitment", Academy of Management Review, Vol (8), No. (3), 486-500, 1983, available: http://amr.aom.org/content/8/3/486.short

[19] Nafei,W. A. "Organizational Silence: Its Destroying Role of Organizational Citizenship Behavior", International Business Research, Vol. (9), No. (5), 57-75, 2016, available: http://www.ccsenet.org/Journal/index.php/ibr/article/view/58196/311 $\underline{03}$

[20] Nikmaram,S. . Yamchi,H. Shojaii,G. S. \& Zahrani.M. A. \& Alvani,S M."Study on Relationship between Organizational Silence and Commitment in Iran", World Applied Sciences Journal, Vol. (17), No. (10): 1271-1277, 2012, available: http://citeseerx.ist.psu.edu/viewdoc/download?doi=10.1.1.389.8965\& $\underline{\text { rep }=\text { rep } 1 \& \text { type }=}$

[21] Nikolaou,I. Vakola, M.,. \& Bourantas, D., "The Role of Silence on Employees' Attitudes "the day after" A merger", Personnel Review, Vol. (40), No. (6), 723-741, 2011, available: http://www.emeraldinsight.com/doi/pdfplus/10.1108/0048348111116 9652.

[22] Norouzi, S. \& Vazifeh Z. , ."Study of the Relationship between Organizational Silence and Organizational Commitment - Case Study: Mashed Railway General Department Employees-", IIOAB Journal, Vol. (7), No. (2), PP: 168-176, 2016, available: http://www.iioab.org/articles/IIOABJ 7.S2 168-176.pdf

[23] Panahi, B. \& Danaeifard, H. "An analysis of Employee's Attitudes in Public Organizations: Explanation of Organizational Silence Climate and Silence Behavior", Transformation Management Journal, Vol. (2), No. (3), PP: 2-19, 2010, available:http://www.ensani.ir/storage/Files/20120426153415-50181.pdf

[24] Panahi, B. S. Veiseh,S. Divkhar,S. \& Kamari .F. "An Empirical Analysis on Influencing Factors on Organizational Silence and its Relationship with Employee's Organizational Commitment", Management Science Letters, Vol. (2) Iss. (3), PP: 735-744., 2012, available: http://www.growingscience.com/msl/Vol2/msl 2012 7.pdf

[25] Park, D. \& Lee,J. "Effects of Cooks' Personality Traits and Organizational Silence on Job Satisfaction and Organizational Commitment-Focus on the Cooks of Deluxe Hotels in Bussan", Journal of Hospitality and Tourism Studies, Vol. (19), No. (5), PP: 261-289, 2016

[26] Pinder, C. C. \& Harlos,K. P. . "Employee Silence: Quiescence and Acquiescence as Responses to Perceived In Justice", Research in Personnel and Human Resources Management, Vol. (20), PP: 331369, 2001, available: http://www.emeraldinsight.com/doi/pdfplus/10.1016/S0742$7301 \% 2801 \% 2920007-3$

[27] Saeed, A. \& Karim, H. "Mediating Role of Organizational Silence on the Effect of Trust on Organizational Commitment -Case Study of Tehran Municipality", Turkish Online Journal of Design Art and Communication, Vol. (6), PP: 1748-1760, 2016, available: http://www.tojdac.org/tojdac/VOLUME6AGUSPCL files/tojdac v06 0AGSE157.pdf
[28] Shirvani, M. Arab,M... Karami, H , Delavari, S. , Kiani, M. M. Survey on the Relationship between Organizational Silence and Management Styles from the Viewpoint of Employees of TUMS General Hospitals 2016, Evidence Based Health Policy, Management \& Economics, 3(1): 23-31., March, 2019

[29] Sobel.M. E. "A systematic interval for indirect effects in structura equations models" In Sociological Methodology, S. Leinhart (ed.), CA: San Francisco: Jossey- Bas. , 2008, pp: 290-312.

[30] Song, H.,.Kim, Y., \& Yoon,.K. "The Effects of Airline Flight Attendant's Perception of Organizational Politics on Organizational Commitment, Silence Behavior and Turnover Intention", Tourism Research, Vol. (41), No. (3), PP: 39-64, 2016.

[31] Sparrowe R. T., \& Liden,R. C. . "Two Routes to Influence: Integrating Leader-member Exchange and Social Network Perspectives", Administrative Science Quarterly, Vol. (50), No. (4), PP: $\quad 505-535, \quad 2005, \quad$ available: http://Journals.sagepub.com/doi/abs/10.2189/asqu.50.4.505

[32] Spigner, K. E., "When silence speaks louder than words: Examining the perceptions and experiences of women who work in faith-based organizations where organizational silence is present." Ph.D. Dissertation, Northeastern University MA: Boston, 2016.

[33] Spreitzer, G. M. . "Social Structural Characteristics of Psychological Empowerment", Academy of Management Journal, Vol. (39), No. (2), PP: 483-504, 1996, available: http://amj.aom.org/content/39/2/483.short

[34] Sugarman, B. . "A Learning-based Approach to Organizational Change: Some Results and Guidelines", Organizational Dynamics, Vol. (30), No. (1), PP: 62-76, 2001.

[35] Tangirala,S. \& Ramanujam,R. "Employee Silence on Critical Work Issues: The Cross level Effects of Procedural Justice Climate", Personnel Psychology, Vol. (61), No. (1), PP: 37- 68, 2008, available: http://onlinelibrary.wiley.com/doi/10.1111/j.1744 6570.2008.00105.x/full

[36] Tulubas, T. \& Celep, C., Effect of perceived procedural justice on faculty members' silence: the mediating role of trust in supervisor, Procedia - Social and Behavioral Sciences, 47, pp: 1221 - 1231, 2012.

[37] Vakola,.M. \& Bouradas, D. "Antecedents and Consequences of Organizational Silence: an Empirical Investigation", Employee Relations, Vol. (27), No. (5), PP: 441-458, 2005, available: http://www.emeraldinsight.com/doi/pdfplus/10.1108/0142545051061 1997

[38] Wang,HY.D.. \& .Hsieh, H-H. Organizational ethical climate, perceived organizational support, and employee silence: A cross-level investigation. Human Relations, 66(6), 783-802, 2013, available: https://doi.org/10.1177/0018726712460706

[39] Yeh, H. \& Shih, C. "The Mediating Effect of Organizational Commitment on Leadership Type and Job Performance", the Journal of Human Resource and Adult Learning, Vol. (8) No. (2), PP: 50-59, 2012, available: https://search.proquest.com/openview/9e14a302fe88938d1dc3094d70 3 c6e66/1?pqorigsite $=$ gscholar \&cbl $=406315$

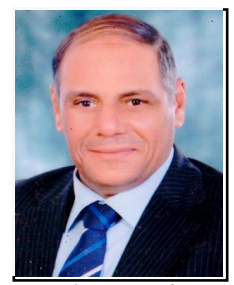

Adel R. M. Rayan.

Prof. Rayan borne in Assiut, Egypt in the first of Jan., 1955. He has been graduated from Assiut University in June 1976. He has been awarded the MSc in Business Administration in Dec., 1982 and the PhD. in Business Administration (HRM) in 1990. He completed his $\mathrm{PhD}$. research work at Assiut University, Egypt and the University of Georgia in Athens, GA, USA. He has been promoted as an associate professor of Business Administration in Jan., 1996 and as a professor of HRM in 2001. He was acting as the chairman of Business Administration Department in Assiut University in 2002-2003, vice-dean of the Faculty of Commerce, Assiut University from Aug., 2003- Sep., 2006, and Dean of the Faculty of Commerce from Sep. 2006- Feb., 2012 and as a Vice-President of Assiut University from. Mar., 2012 - July 2015. Currently, he is acting as the dean of the Faculty of International Busines and Humanities (FIBH) at Egypt - Japan University of Science and Technology.

Prof. Rayan published more than 30 research papers in local, regional and international journals. His research interest include leadership, workrelated stress, and organizational culture, deviant work behavior (e.g. bullying, counterwork behaviors and violence at work). 


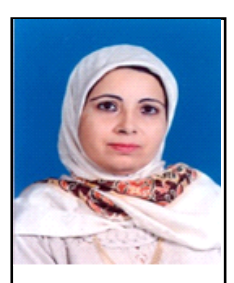

Nadia A. M. Ali.

Prof. Nadia A. M. Ali borne in Qena, Egypt in the $21^{\text {st }}$ of March, 1955. She has been graduated from Assiut University in June 1977. She has been awarded the MSc in Business Administration in 1984 and the PhD. in Business Administration (HRM) in 1998. She completed her PhD. research work at Assiut University, Egypt. She has been promoted as an associate professor of Business Administration in Sep., 2005 and as a professor of HRM in 2015. She was acting as the chairman of Business Administration Department, Faculty of Economics and Administration, University of October 6, 2006/2007, and the chairman of Business Administration Department in Assiut University in 2007-2015. Currently, she is acting as Member of the Commercial Studies Sector Committee of the Supreme Council of Universities in Egypt.

Prof. Nadia A. M. Ali published more than 20 research papers in local, regional and international journals. Her research interests include leadership, Selection and appointment, training, career path, organizational justice, deviant work behaviors (e.g. Bullying, counterproductive work behaviors, and violence at work).

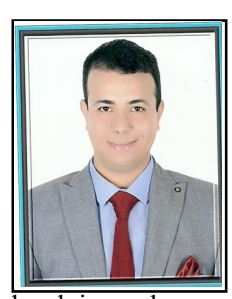

Mostafa S. K. Abdel Monem

Dr. Abdel Monem borne in Assiut, Egypt in the twenty of Sep., 1984. He has been graduated from Assiut University in June

2006. He has been awarded the MSc in Business Administration in Nov., 2013 and the PhD. in Business Administration (Business Administration and Organizational Behavior) in Sep., 2019.

local, journals.

Dr. Abdel Monem published some research papers in

His research interests include Organizational Silence Behavior,

Organizational Commitment and Quality of Training, and Organizational Citizenship Behavior. 